\title{
A Novel Idea for Improving the Efficiency of Green Walls in Urban Environment (an Innovative Design and Technique)
}

\author{
Behrouz Pirouz $^{1, *(\mathbb{D})}$, Michele Turco ${ }^{2}\left(\mathbb{D}\right.$ and Stefania Anna Palermo ${ }^{2}$ (D) \\ 1 Department of Mechanical, Energy and Management Engineering, University of Calabria, \\ 87036 Rende (CS), Italy \\ 2 Department of Civil Engineering, University of Calabria, 87036 Rende (CS), Italy; \\ michele.turco@unical.it (M.T.); Stefania.palermo@unical.it (S.A.P.) \\ * Correspondence: behrouz.pirouz@unical.it; Tel.: +39-0984-496542
}

Received: 15 November 2020; Accepted: 12 December 2020; Published: 15 December 2020

\begin{abstract}
The advantages of low-impact development approaches, such as green walls in an urban environment, are numerous. These systems can be applied for managing stormwater, saving energy consumption, decreasing noise pollution, improving runoff quality, improving life quality, and so forth. Besides, atmospheric water harvesting methods are considered a nonconventional water source. There are many studies about the analysis and advantages of green walls and atmospheric water harvesting conducted separately. However, the use of a combined system that uses fog harvesting in the irrigation of green walls has received less attention in previous studies, and therefore in this research, the feasibility of a novel green wall platform was investigated. At first, the potential of using green walls and atmospheric water harvesting in different climates was analyzed. Then a new combined system was proposed and explained. The study results determined that atmospheric water harvesting can be applied as a source of irrigation for green facilities, particularly in the dry season and in periods with lower precipitation. In the Mediterranean climate, summer fog harvesting yields $1.4-4.6 \mathrm{~L} / \mathrm{m}^{2} /$ day, and the water consumption of green walls is about $4-8 \mathrm{~L} /$ day $/ \mathrm{m}^{2}$. This can improve one issue of green walls in an urban environment, which is irrigation in summer. Furthermore, the novel system would protect plants from severe conditions, improve buildings' thermal behavior by decreasing direct sunlight, and increase conventional green walls' efficiency and advantages.
\end{abstract}

Keywords: green walls; fog water harvesting; saving energy; sustainability; economy

\section{Introduction}

Buildings are responsible for about $40 \%$ of the total energy consumption in cities, and the impact of greening systems is evident $[1,2]$. In addition, greening systems are known as natural cooling systems [3] and have a high potential to reduce energy consumption in buildings [4-6]. The advantages of low-impact development (LID) systems, such as green walls, green roofs $[7,8]$, and rainwater harvesting systems, have been determined in many studies $[9,10]$. In the design of these systems, many elements need to be considered [11], mainly including statistical analysis of hydrological parameters [12], hydrological effectiveness [13], flow measurement devices [14], and thermal impacts $[15,16]$. The other potentials of green walls are improvement of ecosystem services, reduction of urban noise, and improvement of air quality [17].

Reitano [18] analyzed the water conditions in Mediterranean countries. The analysis showed that due to geographical and topographical positions, there are different climate types in the Mediterranean region, and thus the water conditions and design solutions may be different. Therefore, to meet 
the growing water demand, systems such as fog and dew harvesting, rainwater harvesting, reverse osmosis (RO), and any other low-energy system may have some advantages. Jarimi et al. [19] analyzed sustainable methods for harvesting water from atmospheric fogs and dew. They showed that for fog harvesting analysis, the studies could be divided according to the mesh topology, mesh wettability, and collector efficiency and feasibility of the methods. The analysis categories could include a radiative cooling condenser (passive systems), regenerated solar desiccant, and active cooling condensation for dew harvesting. The study results determined that there are several methods for atmospheric water collectors that can produce water at different levels of humidity and geographical locations. Abdul-Wahab and Lea [20] analyzed fog water collection worldwide through a review analysis and presented a theory and application in different locations, such as the Middle East, Africa, and South America. The study explained the fog characteristics, standard fog collectors, and collector materials and design. The collected data from countries in arid regions showed the fog collection's potential as a supplementary water supply. Batisha [21] evaluated the sustainability and feasibility of fog harvesting using a nonconventional method, including analyzing the physical process and different meshes and collectors and cost in comparison with those of other water resources. The analysis of different elements determined the necessity of building a pilot system before investing in a fog water harvesting system.

There could be a long dry period(s) in which green walls (GWs) need supplemental water, and with high-speed winds, GWs are facing problems such as soil loss [22]. To reduce the use of potable water in GWs, an alternative water source is greywater, which needs a specific design and consideration for greywater treatment [23], such as secondary piping with filtering and pump [17].

According to literature reviews, the advantages of green walls and atmospheric water harvesting methods are plenty, and there are many published papers in each of these areas. The knowledge gaps for further studies have been identified in several works, such as those of Medl et al. (2017), Segovia-Cardozo et al. (2019), Koch et al. (2020), and Manso et al. (2021) [17,24-26]. However, still the main focuses of GWs are economic analysis, energy savings, and use of greywater as an alternative water source, and fog harvesting methods are analyzed separately for other purposes, such as potable water resources. A combined method, meaning using fog harvesting for irrigation of green walls in urban environments, has received less attention in previous studies.

Therefore, in this research, the feasibility of a novel platform of green walls was investigated to gain atmospheric water without consuming energy and increase the efficiency and advantages of green walls, particularly in summer with lower precipitation. The main aim of the study was to investigate the potential of fog harvesting and water consumption of green walls in different climates and correlated factors. The second aim was to propose a combined green wall system with less dependence on an urban water resource. The third aim of the study was to address the issues of conventional green walls through an innovative design to improve the usage of the system and increase its advantages in an urban environment.

The design parameters of green walls and atmospheric water harvesting systems would depend on several elements. In this regard, first, the potential of different green wall types and the main design elements was analyzed. Then, fog water harvesting methods and water harvesting amount in different climates were investigated. Finally, a new combined system was proposed and explained.

\section{Materials and Methods}

In this study, the potential of fog water harvesting methods and green walls in different climates would be determined based on different case studies, and a novel system for improving the efficiency of green walls would be presented with an explanation of its application and advantages. An analysis diagram is presented in Figure 1.

As can be seen in the analysis diagram, first, we analyzed green walls and their water consumption in different climates besides their advantages and the issues with conventional green walls. The result of this section could determine the amount of irrigation in summer and the thermal advantages of irrigation and other useful information for the next section. Second, we explored atmospheric water 
harvesting methods in different climates, and the outcomes could show the water harvesting potential per $\mathrm{m}^{2}$ in fog days, especially in summer, in which irrigation of green walls is necessary. Therefore, we evaluated the possibility of applying atmospheric water harvesting methods to irrigate green walls in an urban environment. The bases of these sections of the analysis are previous case studies and literature reviews. Finally, based on the three previous sections, we proposed a novel design for green walls with a higher efficiency in an urban environment, as well as the main usage of the new system. Then, we explained the main issues with conventional GWs and how the new system is supposed to solve them.

\begin{tabular}{|l|l|} 
- Analysis of green walls $(\mathrm{GW})$ and their properties and advantages in different climates besides \\
the main issues in conventional GWs.
\end{tabular}

Figure 1. Analysis diagram of the study.

\section{Results}

\subsection{Green Walls in Different Climates}

Greening systems, such as green walls and green roofs, have several advantages, including environmental $[7,27,28]$, social, and economic benefits [29-32]. These systems are widely used in different climates, and their benefits can change in different contexts. Many studies have emphasized the environmental benefits of green systems in the Mediterranean climate, which are more evident in the hot season than in the cold season [33-40]. In these regions, energy savings can reach $84 \%$ in the hot season. In the tropical climate, the adoption of a greening solution has demonstrated that environmental benefits have less impact compared with that in the Mediterranean climate, but they were also relevant [41-45]. The rate of energy savings in these regions can reach an average of $65 \%$. In the arid climate, the results were not promising, but energy savings can reach the rate of $52 \%$ in the cold season, while energy savings in the hot season are very low $[46,47]$. The same behavior can be assumed for the Continental climate, where no relevant energy savings were recorded in the literature, especially in the hot season [48].

\subsubsection{Different Types of Green Walls and the Main Design Elements}

Green wall (GW) systems are generally divided into two typologies: green facades (GFs) and living walls (LWs), which are different from each other as regards constituent elements and design features. GFs, which are divided into direct and indirect systems, support the natural growth of climbing plants that can achieve up to $25 \mathrm{~m}$ of height and cover a whole wall surface in a few years. The main difference between direct and indirect GFs is the use of a structural support for plant growth. In this regard, direct systems are characterized by plants directly developed on the wall, while in indirect systems, a structural support (continuous or modular guides) sustains the plant's growth. Generally, GFs are easy to install and light and present low costs [29,49]. On the other hand, LWs, the most recent innovation in terms of GW, based on specific climate conditions, can support a wide variety of vegetations (succulents, perennial plants, grasses, etc.). Just like the former category, LWs can 
also be subdivided into continuous and modular LWs, whose main difference is in the substrate soil. In continuous LWs, the plants are put in a pocket obtained by cutting absorbent and lightweight screens (as felt). While modular LWs are generally prevegetated panels with vessels, flexible bags, trays, and planter tiles as supporting elements for the plant's growth, they are characterized by organic and inorganic growing media adequate for retention capacity [29,49].

\subsubsection{Water Consumption of Green Walls}

The water consumption of green walls is essentially due to irrigation, and it may depend on several factors, such as (a) the climate of the area where they are installed, (b) the type of planted vegetation, (c) the type of installed system, (d) the average annual rainfall, (e) the distribution of precipitations, (f) the trend of daytime and nighttime temperatures, and ( $g$ ) the relative humidity ( $\mathrm{RH})$ in the air [50]. Moreover, one advantage of green walls is their thermal impacts on buildings and total energy consumption, and this, especially in summer, would depend on the irrigation. However, water scarcity and precipitation periods could affect irrigation and efficiency, particularly in arid and semiarid areas [15]. Ottelé et al. [51] quantified a green wall's water consumption in a Continental climate with an average wind speed of $5.8 \mathrm{~m} / \mathrm{s}$, which ranged from 1 to $3 \mathrm{~L} /$ day per $\mathrm{m}^{2}$ depending on the system investigated. Pérez-Urrestarazu et al. [52] analyzed the water consumption of an experimental LW system with a size of $5.9 \mathrm{~m}^{2}$ in Spain, Seville (Mediterranean climate), and the results determined a range from 4.0 to $8.0 \mathrm{~L} / \mathrm{d} / \mathrm{m}^{2}$.

\subsubsection{The Relative Humidity in the Air and the Area near Green Walls}

Several studies have demonstrated that GW use contributes to the stable relative humidity of a building, improving climate conditions. Chen et al. [53] investigated RH's role in two identical thermal labs built for this purpose. Their study concluded that the use of green walls provided a more stable relative humidity condition in the air layer next to the wall surface without increasing the mean relative humidity of the indoor space. Widiastuti et al. [54] found in their study an increase in $\mathrm{RH}$ from $65 \%$ to $72 \%$.

$\mathrm{RH}$ is an important factor for atmospheric water harvesting as explained in the next section. The results of a study that analyzed two case studies showed that the potential of water harvesting depends on relative humidity, and it would be near zero with RH at less than 69\% [55].

\subsection{Fog Water Harvesting Methods and Their Potential in Different Climates}

Sabino [56] analyzed fog harvesting pilot sites in the archipelago of Cape Verde, which has a desert climate and an altitude between 750 and $1400 \mathrm{~m}$. The daily collected water was reported to be between 3 and $75 \mathrm{l} / \mathrm{m}^{2} /$ day. Cereceda et al. [57] investigated the fog harvesting potential in Chile, which has a desert climate. The analysis determined that fog is frequently observed in the coastal area (0-12 km seashores) with a harvesting capacity of about $7 \mathrm{~L} / \mathrm{m}^{2} /$ day. Estrela et al. [58] analyzed fog harvesting using a passive cylindrical collector in four locations in Spain. Their results indicated the significant potential of the method in the selected regions. The water produced was between 2 and $7 \mathrm{~L} / \mathrm{m}^{2} /$ day. The maximum summer fog was also determined, which was $4.6 \mathrm{~L} / \mathrm{m}^{2} /$ day. Harb et al. [59] explored the possibility of fog harvesting to improve the situation of water shortage in Egypt, and the results showed the effectiveness of the method. Lekouch et al. [60] analyzed fog and dew harvesting performance by using a passive condenser and mesh collector in Morocco, which has an arid climate, and the results showed the effectiveness of the method. Dodsona and Bargach [61] explored the possibility of fog water harvesting in the southern region of Morocco, which has a semiarid climate. Their pilot site's annual yield with a mesh size of $600 \mathrm{~m}^{2}$ was 2.3 million liters $\left(10.5 \mathrm{~L} / \mathrm{m}^{2} /\right.$ day).

Park et al. [62] studied the role of surface wettability on the efficiency of fog harvesting. Their analysis determined that in a mild fog with a wind speed of $2 \mathrm{~m} / \mathrm{s}$, an average radius of droplets of about $3 \mu \mathrm{m}$, and a liquid water content of $0.1 \mathrm{~g} / \mathrm{m}^{3}$, the water harvesting capacity could be about $2 \mathrm{~L} / \mathrm{m}^{2} /$ day if the used mesh is dip-coated. Almasian et al. [63] analyzed the role of modified 
nanofiber in the capacity of fog harvesting. The analysis showed that by increasing the hydrophobic nature of the material, the harvesting capacity increases. Therefore, they investigated a new type of fluorinated nanofibers with a super-hydrophobic nature, which means lower surface energy, higher water contact angle, and higher surface roughness. The capacity of the treated nanofibers was about 10 times more than that of the untreated nanofibers. In another study by Zhou et al. [64], a new hybrid surface was prepared and fog harvesting ability was investigated. Analysis of the new hybrid hydrophobic-hydrophilic surface integrated with a Janus copper foam system (HB-HL + JCF) showed that the efficiency of fog collection compared with untreated copper foam increased by $209 \%$.

Ghosh et al. [65] explored the fog harvesting from a thermal power plant's cooling tower since it is considered a major industrial water consumer. The pilot analysis results determined that a recovery of about $40 \%$ could be possible by using fog harvesting $\left(10.5 \mathrm{~m}^{3}\right.$ per hour in a $500 \mathrm{MW}$ power plant). In a more recent study, Ghosh et al. [66] investigated the use of a coating mesh to increase the efficiency of a metal mesh for fog harvesting and contaminants. The results showed that coated metal meshes made of $\mathrm{TiO}_{2} / \mathrm{ZnO}$ could be applied for this purpose. Bagheri [67] developed an experimental setup for analyzing water harvesting in commercially atmospheric water harvesting systems. The results showed that the average water harvesting in a cold and humid climate is about $0.05 \mathrm{~L} / \mathrm{h}$ (with an energy consumption of $6.23 \mathrm{kWh} / \mathrm{L}$ ), and in warm and humid climates, around $0.65 \mathrm{~L} / \mathrm{h}$ (with an energy consumption of $1.02 \mathrm{kWh} / \mathrm{L}$ ).

Standard collectors from polypropylene mesh nets can be classified as follows [68,69]:

- Standard fog collectors (SFCs): $1 \times 1\left(1-1.5 \mathrm{~m}^{2}\right)$ and $2 \mathrm{~m}$ above the ground

- Large fog collectors (LFCs): $4 \times 10\left(40 \mathrm{~m}^{2}\right)$ or $12 \times 4\left(48 \mathrm{~m}^{2}\right)$ and $2 \mathrm{~m}$ above the ground, and the ratio of width to height is usually 2.5 and 3 .

The analysis showed that the efficiency of fog harvesting depends on the moisture capture by the mesh and the captured water removal from the mesh [70]. In estimating the potential Fog Water Collection (FWCP), two critical factors are visibility and wind speed [71]. SFCs can harvest fog when winds are present; however, the efficiency can be decreased by winds parallel to the panel [58]. Contact angle is another important factor, allowing small captured droplets to easily slide down into the collector [62]. Furthermore, water harvesting capacity would depend on the geometrical shapes of the Raschel mesh [72]. Another factor that needs to be considered is the sustainability of the techniques [73,74] and, in this case, the sustainability of the used mesh and installation structures [75].

The efficiency of fog collection depends on wind velocity, fog liquid water content, droplet size distribution, and mesh characteristics, which can be calculated as follows [76]:

$$
\eta_{\text {coll }}=\frac{\dot{W}_{\text {coll }}}{v_{0} L W C}
$$

$\eta$ coll-the water collector efficiency

$\dot{W}_{\text {coll }}$-the collected water flow rate per unit of mesh area $\left(\frac{\frac{k g}{s}}{\mathrm{~m}^{2}}\right)$

vo-the wind flow velocity $\left(\frac{m}{s}\right)$

LWC $\left(\frac{\mathrm{kg}}{\mathrm{m}^{3}}\right)$ - the liquid water content of the airflow

Some of the maintenance issues that currently exist in LFCs are as follows [75]:

- The wind pressure on the mesh can break the supporting structures;

- The mesh and other components can be damaged by UV radiation.

The potential of fog harvesting in different case studies and climates is presented in Table 1. 
Table 1. The potential of fog water harvesting in different case studies and climate types.

\begin{tabular}{|c|c|c|c|c|c|c|c|c|c|}
\hline Climate Type & Location & Type & Size $\left(m^{2}\right)$ & EL (m) & WH in Summer (L. Day) & WH (L. Fog Day) & Cost & Year & Ref. \\
\hline \multirow{2}{*}{$\begin{array}{l}\text { Different } \\
\text { climates }\end{array}$} & \multirow{2}{*}{ Different sites } & LFSs & 48 & - & - & $150-750$ & 400 & \multirow{2}{*}{2011} & \multirow{2}{*}{ [18] } \\
\hline & & SFCs & 1 & - & - & - & $100-200$ & & \\
\hline \multirow{2}{*}{ Desert } & \multirow{2}{*}{ Alto Patache, Chile } & SFC & 1.1 & 700 & - & 6 & - & 1987 & {$[77]$} \\
\hline & & SFC & 1 & 700 & - & 7.8 & - & 2000 & [78] \\
\hline Tropical & Tojquia, Guatemala & 35 LFCs & 1680 & 3300 & - & 6300 & - & 2006 & [68] \\
\hline Tropical & Tojquia, Guatemala & 40 LFCs & 1920 & 3300 & - & 8000 & - & 2006 & [79] \\
\hline Tropical & Yemen (Hajjah mountains) & 25 LFCs & 28 & 1800 & - & 4.5 & - & 2004 & [80] \\
\hline $\begin{array}{l}\text { Subtropical } \\
\text { Dry arid }\end{array}$ & Abadan, Iran & SFC & 1 & 3 & - & 6.7 & - & 2013 & {$[55]$} \\
\hline Hot desert & Chabahar, Iran & SFC & 1 & 7 & - & 8.6 & - & 2012 & [81] \\
\hline \multirow{4}{*}{$\begin{array}{c}\text { Mediterranean } \\
\text { (Coastal area) }\end{array}$} & Valencia Peñagolosa & \multirow{4}{*}{$\begin{array}{l}\text { Cylindrical } \\
\text { collector } \\
\text { (D: } 26 \mathrm{~cm} \text {, } \\
\mathrm{H}: 46 \mathrm{~cm})\end{array}$} & \multirow{4}{*}{1} & 1193 & 2.5 & 2.9 & \multirow{4}{*}{-} & \multirow{4}{*}{2004} & \multirow{4}{*}[58]{} \\
\hline & Valencia Monduver & & & 843 & 1.6 & 7.3 & & & \\
\hline & Valencia Bartolo & & & 763 & 1.4 & 2 & & & \\
\hline & Valencia Montgo & & & 670 & 4.6 & 7 & & & \\
\hline Mediterranean & Morocco & LFCs & 600 & 1225 & - & 6300 & 200 & 2015 & [61] \\
\hline Subtropical & Kathmandu, Nepal & LFCs & 80 & 1400 & - & 500 & - & 2010 & [82] \\
\hline Arid tropical & Peru & SFC & 1 & 800 & - & 11.8 & - & 1999 & [83] \\
\hline Mediterranean & South Africa & SFC & 1 & 1600 & - & - & 4.6 & 2001 & [84] \\
\hline \multirow{3}{*}{$\begin{array}{l}\text { Different } \\
\text { climate }\end{array}$} & \multirow{3}{*}{ Different sites } & SFC & 1 & - & - & - & $25-50$ & 2015 & {$[85,86]$} \\
\hline & & LFCs & 40 & - & - & - & $1000-2000$ & \multirow{2}{*}{2018} & \multirow{2}{*}{ [87] } \\
\hline & & LFCs & 48 & - & - & - & $1200-2400$ & & \\
\hline
\end{tabular}

EL: elevation; WH: water harvested; SFC: Standard fog collectors; LFC: Large fog collectors. 


\subsection{The New Proposed Green Wall System}

The new green wall (living wall) platform with an atmospheric water harvesting and collector system is presented in Figures 2 and 3, and the installation of the platforms in buildings in Figure 4.

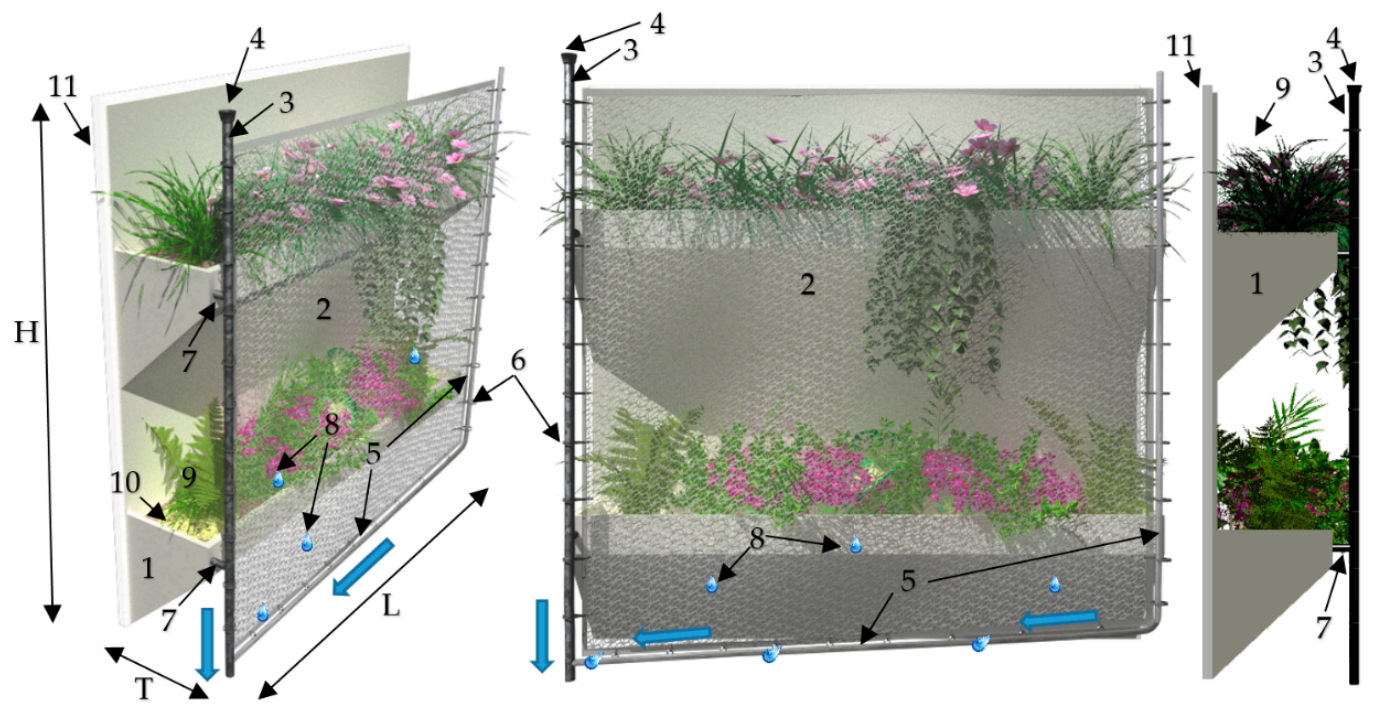

Figure 2. The novel living wall platform with a fog harvesting mesh. 1-living wall platform, 2-mesh for fog harvesting, 3-water collector pipe, 4-funnel that is connected to the collector pipe to collect water drops, 5-rod for conveying drops to the collector pipe, 6-metal clamp to fix the mesh to the pipe and rod, 7-support to fix the mesh system to the green wall platform, 8-water droplets, 9-plants, 10-soil, 11-frame to fix the living wall to the wall of the building, $\mathrm{H}$ - height of the platform, L-length of the platform, T-thickness of the platform.

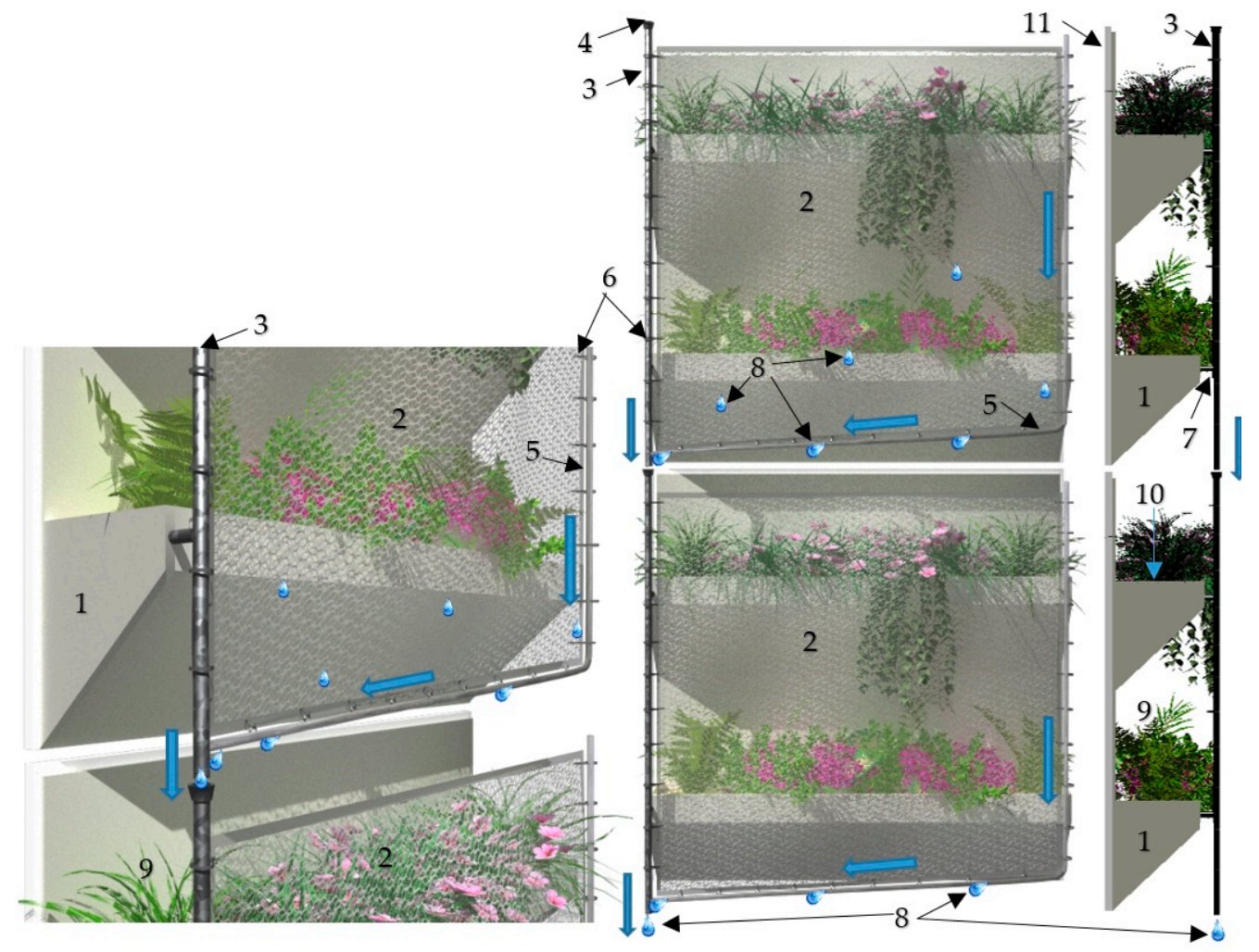

Figure 3. The installation of two novel living wall systems and the water droplets' movement. 


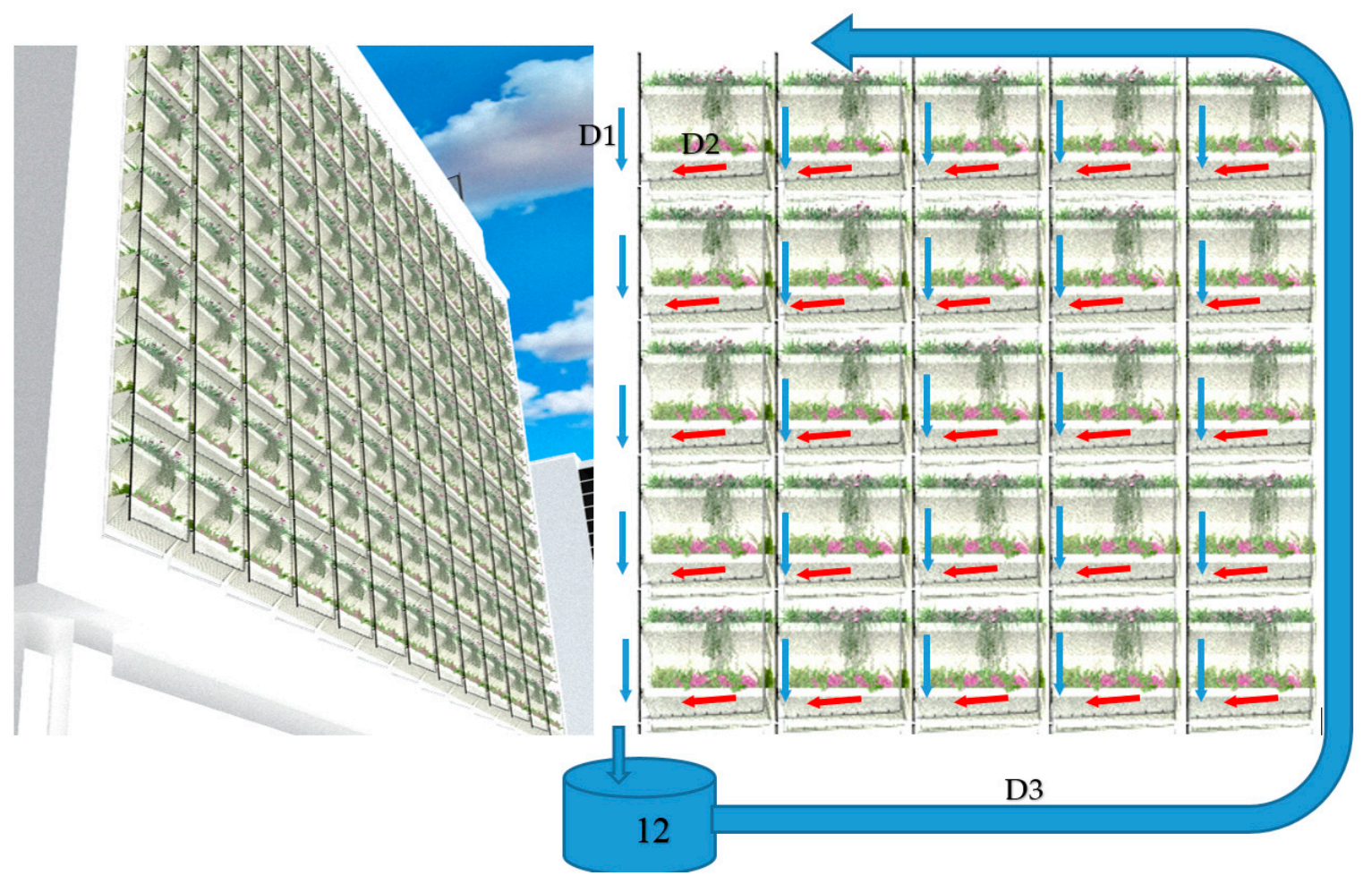

Figure 4. The view of the combined living wall system after installation of all platforms. 12-water storage tank with filters, D1-direction of water droplets to the downside collector pipe, D2-direction of the water droplets on the slopped rods, D3 - the way of using harvested water for irrigation or other usages in the buildings.

As can be seen in the figures, the water harvesting mesh (2) produces droplets (6) that move through the sloped rod (4) and then enter the collector pipes (3), and the collected water drops from each living wall platform (1) and discharges on the next one on the downside.

\subsubsection{The Main Elements in the Novel Living Wall System}

- Green wall (living wall) platform, H (height) and L (length): 50 to $200 \mathrm{~cm}, \mathrm{~T}$ (thickness): 15 to $35 \mathrm{~cm}$;

- Fog harvesting mesh that is a coated double-layer transparent mesh (polypropylene ribbon) with hydrophobic materials, such as $\mathrm{BaSO}_{4}, \mathrm{TiO}_{2}$, and $\mathrm{ZnO}$;

- Metal rod for fog convey (the collected fog droplets can move on the sloped rod and reach the collector pipe);

- Water collector pipe (the water drops can pour from each green wall panel to another);

- Metal base for mesh installation to the living wall platform and metal clamps to fix the mesh to the base;

- Water storage tank with filters can store the collected water for the green wall's irrigation and other nonpotable purposes.

\subsubsection{Different Uses of the New Proposed Living Wall System}

- For atmospheric water harvesting in an urban environment;

- For improving the thermal impact of buildings;

- For improving the efficiency of green walls in water consumption and noise and air pollutions reduction;

- For improving the sustainability of municipalities, factories, and buildings in different climates. 


\section{Discussion}

Green walls are widely used in different climates, and their benefits can change in different contexts. The environmental benefits of green systems in different climates are more evident in the hot season than in the cold season as energy savings in summer can reach $84 \%$ in the Mediterranean climate, $65 \%$ in the tropical climate, and $52 \%$ in the arid climate. The water consumption of green walls, which affects thermal impacts, would depend on the irrigation, especially in summer. According to previous studies, the water consumption is 4 to $8 \mathrm{~L} /$ day $/ \mathrm{m}^{2}$ in the Mediterranean climate and 1 to $3 \mathrm{~L} / \mathrm{day} / \mathrm{m}^{2}$ in the Continental climate. The analysis shows the irrigation demands for green walls, specifically in the dry seasons. However, in dry and semidry climates and even in the Mediterranean climate, whereas the annual rainfall may exceed $1000 \mathrm{~mm}$, the dry period (July to September) could have no, or in some years low, precipitation.

One way to provide the required water for GWs could be to use a fog harvesting mesh. The potential of fog harvesting based on previous studies, which also depends on altitude, is 2 to $7 \mathrm{~L} / \mathrm{m}^{2} /$ day in the Mediterranean climate (maximum summer fog from 1.4 to $4.6 \mathrm{~L} / \mathrm{m}^{2} /$ day), $11.8 \mathrm{~L} / \mathrm{m}^{2} /$ day in the arid tropical climate, $10.5 \mathrm{~L} / \mathrm{m}^{2} /$ day in the semiarid climate, $7 \mathrm{~L} / \mathrm{m}^{2} /$ day in the desert climate, and $8.6 \mathrm{~L} / \mathrm{m}^{2} /$ day in the hot desert climate. Furthermore, there are some techniques for improving the efficiency of a fog harvesting mesh. The efficiency of a fog harvesting mesh depends on hydrophobic-hydrophilic conditions, which means the moisture captured by the mesh and the captured water removal from the mesh. This efficiency can be improved by using coated meshes made of $\mathrm{TiO}_{2} / \mathrm{ZnO}$.

Comparisons have determined that in the Mediterranean climate, summer fog harvesting, which yields $1.4-4.6 \mathrm{~L} / \mathrm{m}^{2} /$ day, could be an appropriate source of irrigation as the water consumption of green walls is about 4 to $8 \mathrm{~L} / \mathrm{day} / \mathrm{m}^{2}$. In addition, GWs increase the relative humidity in the surrounding area, and the potential of atmospheric water harvesting depends on the RH. While the result of a study showed that the fog harvesting potential is low in RH less than $69 \%$, the analysis of another study showed that the use of green walls can increase RH from $65 \%$ to $72 \%$, which could be enough to use atmospheric water harvesting methods.

\subsection{The Advantages of the New Proposed Living Wall System}

The main advantages of the new living wall platforms compared with conventional ones are as follows:

- In conventional green wall systems for installation, many in-site construction works were required, but in the new system, the platforms, with a specific design (shape, size, and installation method), make installation easy, and in several stages based on budget.

- In conventional green wall systems, all systems could be stopped for a repair, but in the new system, the repair can be done just on the damaged platform very fast (by removing and replacing the damaged platform with a new one), which decreases the maintenance cost. In addition, a combination of a sloped rod and a pipeline in the fog water collecting system decreases the total cost. In this system, the water droplets (fog/precipitations) move through the sloped rod through gravity and reach the water collector pipe, and from each platform to the downside platform.

- In conventional green wall systems, the focuses are landscape, thermal impacts (confronted with issues), and in some cases, runoff management. However, in the newly designed platform, the transparent mesh keeps the landscape of plants in the living wall and improves the thermal impacts and stormwater management and reduces noise and air pollution besides protecting the plants from direct sunlight, high wind speed, and snow.

- Green walls can reduce the total runoff volume and reduce and delay the peak discharge into the sewer system $[7,13,88-90]$. The performance would be improved in the new system since part of the precipitation can be collected by the installed mesh.

- According to literature analysis, green walls can increase the surrounding air's relative humidity through its wet substrate and the evapotranspiration of plants. This can improve atmospheric 
harvesting systems' efficiency since it directly depends on the $\mathrm{RH} \%$, and the relative humidity in the site of green walls is more than that in the adjacent area. Thus, this phenomenon undoubtedly increases the possibility of generating water with the systems mentioned in this study, but also, the excessive increment of this parameter could be critical considering the alteration of the climatic condition, especially in the humid climate.

- In the new system, the necessity of irrigating green walls, particularly in dry periods, is decreased by a transparent fog harvesting mesh and, as a result, reduces the pressure on the water resource.

- Green walls can reduce energy consumption in buildings [15,39,91-93] and mitigate the urban heat island [94-97]. In conventional green wall systems, the thermal efficiency of green walls decreases in dry periods due to water issues for irrigation, but in the new proposed system with a transparent mesh in the front, thermal efficiency is increased and water consumption is decreased in several ways. First, the mesh absorbs fog/precipitation and parts of the evapotranspiration of the plants. The thermal performance would increase due to the increase in irrigation in the summer. Second, the installed mesh decreases the plants' direct exposure sunlight and decreases the total water consumption.

- In conventional green wall systems, the plants could be damaged by high wind speed and snow conditions, but these two problems are solved in the new platform with an installed transparent mesh in front of the plants.

- Green walls can enhance the water quality $[89,98,99]$, improve the air pollution concentration, and decrease the noise levels in urban environments [100-102]. In the new system, the performance improved due to the installed mesh.

- Green walls can improve the wildlife and biodiversity conditions [103-105]. The same performance would be available in the new systems.

- Green walls can improve the building's aesthetic and property values and quality of life [106-108]. The same results would be achieved in the new systems. However, the total cost of water and energy demand in the new systems are less than those of previous systems.

- A main part of the cost of the fog harvesting mesh belongs to the supporting structures that stop collapse owing to winds, which affects the final price [75]. However, in the new system, the mesh is installed to the living walls' platform and does not need separate structures, which decreases the entire coast.

\subsection{Recommendation for Future Works}

The fog mesh's efficiency would depend on the type and distance from the green wall, and therefore, the place of the fog harvesting mesh is recommended for future analysis. In addition, to be confident about the exact impact of the mesh on total water reduction or thermal impact, an experimental analysis is necessary and thus is recommended for future studies. Finally, the evaluation of the mentioned advantages and the analysis of the performance in each point (cost analysis, water quality, etc.) could be done by experimental analysis.

\section{Conclusions}

Different studies have determined the application, properties, and advantages of green walls in an urban environment, which are mainly managing stormwater, saving energy consumption, decreasing noise pollution, improving runoff quality, and improving life quality. Green walls' daily water consumption depends on the climate type and ranges from 1 to $8 \mathrm{~L} / \mathrm{m}^{2} /$ day, and their thermal impacts, especially in summer, depend on the irrigation. However, analysis showed that in dry and semidry climates and even in the Mediterranean climate with annual rainfall of more than $1000 \mathrm{~mm}$, the dry period (July to September) could have no, or in some years low, precipitation.

In addition, analysis of different case studies determined the potential of fog harvesting as a supplementary water supply even in arid regions. The average daily fog-collected water in different 
climates was between 2 and $15 \mathrm{l} / \mathrm{m}^{2}$ in fog days, including 2-7 L/m²/day in the Mediterranean climate, $3.75-4.5 \mathrm{~L} / \mathrm{m}^{2} /$ day in the tropical climate, $6.7 \mathrm{~L} / \mathrm{m}^{2} /$ day in the subtropical dry arid climate, $10.5 \mathrm{~L} / \mathrm{m}^{2} /$ day in the semiarid climate, $5.5-7.8 \mathrm{~L} / \mathrm{m}^{2} /$ day in the desert climate, and $8.6 \mathrm{~L} / \mathrm{m}^{2} /$ day in the hot desert climate, which also depends on the elevation, wind speed, and mesh characteristics. The analysis determined that one way to provide the required water for GWs could be to use a fog harvesting mesh as in the Mediterranean climate, summer fog harvesting, which yields $1.4-4.6 \mathrm{~L} / \mathrm{m}^{2} /$ day, could be an appropriate source of irrigation as the water consumption of green walls is about 4 to $8 \mathrm{~L} /$ day $/ \mathrm{m}^{2}$.

Therefore, a new platform of living walls that benefits from a fog harvesting mesh is developed and analyzed. The analysis shows that, compared with conventional green wall systems, the new system may require less installation time and maintenance costs and could be more economical. Furthermore, the newly designed platform gains atmospheric water without consuming energy and could increase the efficiency and advantages of green walls, particularly in summer with lower precipitation. The transparent mesh used in the new living wall could keep the landscape of the plants; improve thermal performance, stormwater management, and water quality; reduce noise and air pollution; decrease water consumption; and protect the plants from direct sunlight, high wind speed, and snow. In conclusion, it seems that the new proposed systems for living walls would improve the advantages of green walls and may decrease conventional systems' negative points. However, future experimental analysis is required to determine the exact impact on each sector. This idea, after further experimental investigations, could be added to the new energy policies, such as nearly zero-energy buildings (NZEBs).

\section{Patents}

The manuscript's idea is submitted as a patent in Italy's Ministero dello sviluppo economico, with application number 102020000027038.

Author Contributions: Conceptualization, B.P.; methodology, B.P.; data curation, B.P., M.T., and S.A.P.; formal analysis, B.P., M.T., and S.A.P.; investigation, B.P., M.T., and S.A.P.; writing-original draft preparation, B.P., M.T., and S.A.P.; writing - review and editing, B.P., M.T., and S.A.P.; supervision, S.A.P. All authors have read and agreed to the published version of the manuscript.

Funding: This research received no external funding.

Conflicts of Interest: The authors declare no conflict of interest.

\section{References}

1. Bevilacqua, P.; Benevento, F.; Bruno, R.; Arcuri, N. Are Trombe walls suitable passive systems for the reduction of the yearly building energy requirements? Energy 2019, 185, 554-566. [CrossRef]

2. Bevilacqua, P.; Perrella, S.; Bruno, R.; Arcuri, N. An accurate thermal model for the PV electric generation prediction: Long-term validation in different climatic conditions. Renew. Energy 2020, 163, 1092-1112. [CrossRef]

3. Bevilacqua, P.; Bruno, R.; Arcuri, N. Green roofs in a Mediterranean climate: Energy performances based on in-situ experimental data. Renew. Energy 2020, 152, 1414-1430. [CrossRef]

4. Bruno, R.; Bevilacqua, P.; Arcuri, N. Assessing cooling energy demands with the EN ISO 52016-1 quasi-steady approach in the Mediterranean area. J. Build. Eng. 2019, 24, 100740. [CrossRef]

5. Bevilacqua, P.; Bruno, R.; Arcuri, N. Comparing the performances of different cooling strategies to increase photovoltaic electric performance in different meteorological conditions. Energy 2020, 195, 116950. [CrossRef]

6. Pirouz, B.; Palermo, S.A.; Maiolo, M.; Arcuri, N.; Piro, P. Decreasing Water Footprint of Electricity and Heat by Extensive Green Roofs: Case of Southern Italy. Sustainability 2020, 12, 10178. [CrossRef]

7. Palermo, S.A.; Talarico, V.C.; Turco, M. On the LID systems effectiveness for urban stormwater management: Case study in Southern Italy. IOP Conf. Ser. Earth Environ. Sci. 2020, 410, 12012. [CrossRef]

8. Turco, M.; Brunetti, G.; Palermo, S.A.; Capano, G.; Grossi, G.; Maiolo, M.; Piro, P. On the environmental benefits of a permeable pavement: Metals potential removal efficiency and Life Cycle Assessment. Urban Water J. 2020, 1-9. [CrossRef] 
9. Pirouz, B.; Palermo, S.A.; Turco, M.; Piro, P. New Mathematical Optimization Approaches for LID Systems. In NUMTA 2019: Numerical Computations: Theory and Algorithm; Lecture Notes in Computer Science; Sergeyev, Y., Kvasov, D., Eds.; Spinger: Cham, Switzerland, 2020; Volume 11973, pp. 583-595. [CrossRef]

10. Palermo, S.A.; Talarico, V.C.; Pirouz, B. Optimizing Rainwater Harvesting Systems for Non-potable Water Uses and Surface Runoff Mitigation. In NUMTA 2019: Numerical Computations: Theory and Algorithm; Lecture Notes in Computer Science; Sergeyev, Y., Kvasov, D., Eds.; Springer: Cham, Switzerland, 2020; Volume 11973, pp. 570-582. [CrossRef]

11. Maiolo, M.; Carini, M.; Capano, G.; Piro, P. Synthetic sustainability index (SSI) based on life cycle assessment approach of low impact development in the Mediterranean area. Cogent Eng. 2017, 4, 1410272. [CrossRef]

12. Garofalo, G.; Palermo, S.; Principato, F.; Theodosiou, T.; Piro, P. The influence of hydrologic parameters on the hydraulic efficiency of an extensive green roof in Mediterranean area. Water 2016, 8, 44. [CrossRef]

13. Palermo, S.A.; Turco, M.; Principato, F.; Piro, P. Hydrological effectiveness of an extensive green roof in Mediterranean climate. Water 2019, 11, 1378. [CrossRef]

14. Piro, P.; Carbone, M.; Morimanno, F.; Palermo, S.A. Simple flowmeter device for LID systems: From laboratory procedure to full-scale implementation. Flow Meas. Instrum. 2019, 65, 240-249. [CrossRef]

15. Maiolo, M.; Pirouz, B.; Bruno, R.; Palermo, S.A.; Arcuri, N.; Piro, P. The role of the extensive green roofs on decreasing building energy consumption in the mediterranean climate. Sustainability 2020, 12, 359. [CrossRef]

16. Pirouz, B.; Maiolo, M. The role of power consumption and type of air conditioner in direct and indirect water consumption. J. Sustain. Dev. Energy Water Environ. Syst. 2018, 6, 665-673. [CrossRef]

17. Manso, M.; Teotónio, I.; Silva, C.M.; Cruz, C.O. Green roof and green wall benefits and costs: A review of the quantitative evidence. Renew. Sustain. Energy Rev. 2021, 135, 110111. [CrossRef]

18. Reitano, R. Water harvesting and water collection systems in Mediterranean area. the case of Malta. Procedia Eng. 2011, 21, 81-88. [CrossRef]

19. Jarimi, H.; Powell, R.; Riffat, S. Review of sustainable methods for atmospheric water harvesting. Int. J. Low Carbon Technol. 2020, 15, 253-276. [CrossRef]

20. Abdul-Wahab, S.A.; Lea, V. Reviewing fog water collection worldwide and in Oman. Int. J. Environ. Stud. 2008, 65, 487-500. [CrossRef]

21. Batisha, A.F. Feasibility and sustainability of fog harvesting. Sustain. Water Qual. Ecol. 2015, 6, 1-10. [CrossRef]

22. Riley, B. The state of the art of living walls: Lessons learned. Build. Environ. 2017, 114, 219-232. [CrossRef]

23. Fowdar, H.S.; Hatt, B.E.; Breen, P.; Cook, P.L.M.; Deletic, A. Designing living walls for greywater treatment. Water Res. 2017, 110, 218-232. [CrossRef] [PubMed]

24. Segovia-Cardozo, D.A.; Rodríguez-Sinobas, L.; Zubelzu, S. Living green walls: Estimation of water requirements and assessment of irrigation management. Urban For. Urban Green. 2019, 46, 126458. [CrossRef]

25. Medl, A.; Mayr, S.; Rauch, H.P.; Weihs, P.; Florineth, F. Microclimatic conditions of 'Green Walls', a new restoration technique for steep slopes based on a steel grid construction. Ecol. Eng. 2017, 101, 39-45. [CrossRef]

26. Koch, K.; Ysebaert, T.; Denys, S.; Samson, R. Urban heat stress mitigation potential of green walls: A review. Urban For. Urban Green. 2020, 55, 126843. [CrossRef]

27. Brunetti, G.; Turco, M.; Carbone, M.; Maiolo, M.; Piro, P. Modelling the hydraulic behaviour of green roofs through a semi-conceptual reservoir element model. In Proceedings of the International Multidisciplinary Scientific GeoConference Surveying Geology and Mining Ecology Management, SGEM, Albena, Bulgaria, 30 June-9 July 2018.

28. Carbone, M.; Turco, M.; Nigro, G.; Piro, P. Modeling of hydraulic behaviour of green roof in catchment scale. In Proceedings of the International Multidisciplinary Scientific GeoConference Surveying Geology and Mining Ecology Management, SGEM, Albena, Bulgaria, 17-26 June 2014; Volume 1.

29. Manso, M.; Castro-Gomes, J. Green wall systems: A review of their characteristics. Renew. Sustain. Energy Rev. 2015, 41, 863-871. [CrossRef]

30. Li, Y.; Babcock, R.W. Green roof hydrologic performance and modeling: A review. Water Sci. Technol. 2014, 69, 727-738. [CrossRef]

31. Shafique, M.; Kim, R.; Rafiq, M. Green roof benefits, opportunities and challenges-A review. Renew. Sustain. Energy Rev. 2018, 90, 757-773. [CrossRef] 
32. Sadeghian, M.M. A Review on Green Wall, Classification and Function. Int. J. Sci. Res. Sci. Technol. 2016, 2, 47-51.

33. Brunetti, G.; Porti, M.; Piro, P. Multi-level numerical and statistical analysis of the hygrothermal behavior of a non-vegetated green roof in a mediterranean climate. Appl. Energy 2018, 221, 204-219. [CrossRef]

34. Brunetti, G.; Šimůnek, J.; Piro, P. A Comprehensive Analysis of the Variably Saturated Hydraulic Behavior of a Green Roof in a Mediterranean Climate. Vadose Zone J. 2016, 15, 1-17. [CrossRef]

35. Palla, A.; Gnecco, I. Hydrologic modeling of Low Impact Development systems at the urban catchment scale. J. Hydrol. 2015, 528, 361-368. [CrossRef]

36. Palla, A.; Sansalone, J.J.; Gnecco, I.; Lanza, L.G. Storm water infiltration in a monitored green roof for hydrologic restoration. Water Sci. Technol. 2011, 64, 766-773. [CrossRef] [PubMed]

37. Fioretti, R.; Palla, A.; Lanza, L.G.; Principi, P. Green roof energy and water related performance in the Mediterranean climate. Build. Environ. 2010, 45, 1890-1904. [CrossRef]

38. Coma, J.; Pérez, G.; de Gracia, A.; Burés, S.; Urrestarazu, M.; Cabeza, L.F. Vertical greenery systems for energy savings in buildings: A comparative study between green walls and green facades. Build. Environ. 2017, 111, 228-237. [CrossRef]

39. Pérez, G.; Coma, J.; Sol, S.; Cabeza, L.F. Green facade for energy savings in buildings: The influence of leaf area index and facade orientation on the shadow effect. Appl. Energy 2017, 187, 424-437. [CrossRef]

40. Perini, K.; Bazzocchi, F.; Croci, L.; Magliocco, A.; Cattaneo, E. The use of vertical greening systems to reduce the energy demand for air conditioning. Field monitoring in Mediterranean climate. Energy Build. 2017, 143, 35-42. [CrossRef]

41. Wong, N.H.; Cheong, D.K.W.; Yan, H.; Soh, J.; Ong, C.L.; Sia, A. The effects of rooftop garden on energy consumption of a commercial building in Singapore. Energy Build. 2003, 35, 353-364. [CrossRef]

42. Zaid, S.M.; Perisamy, E.; Hussein, H.; Myeda, N.E.; Zainon, N. Vertical Greenery System in urban tropical climate and its carbon sequestration potential: A review. Ecol. Indic. 2018, 91, 57-70. [CrossRef]

43. Qin, X. A Green Roof Test Bed for Stormwater Management and Reduction of Urban Heat Island Effect in Singapore. Br. J. Environ. Clim. Chang. 2013, 410-420. [CrossRef]

44. Kasmin, H.; Stovin, V.; De-ville, S. Evaluation of Green Roof Hydrological Performance in a Malaysian Context. In Proceedings of the 13th International Conference on Urban Drainage, Sarawak, Malaysia, 7-12 September 2014; pp. 1-9. [CrossRef]

45. Wong, N.H.; Kwang Tan, A.Y.; Chen, Y.; Sekar, K.; Tan, P.Y.; Chan, D.; Chiang, K.; Wong, N.C. Thermal evaluation of vertical greenery systems for building walls. Build. Environ. 2010, 45, 663-672. [CrossRef]

46. Zinzi, M.; Agnoli, S. Cool and green roofs. An energy and comfort comparison between passive cooling and mitigation urban heat island techniques for residential buildings in the Mediterranean region. Energy Build. 2012, 55. [CrossRef]

47. Sims, A.W.; Robinson, C.E.; Smart, C.C.; Voogt, J.A.; Hay, G.J.; Lundholm, J.T.; Powers, B.; O'Carroll, D.M. Retention performance of green roofs in three different climate regions. J. Hydrol. 2016, 542, 115-124. [CrossRef]

48. Alexandri, E.; Jones, P. Temperature decreases in an urban canyon due to green walls and green roofs in diverse climates. Build. Environ. 2008, 43, 480-493. [CrossRef]

49. Palermo, S.A.; Turco, M. Green Wall systems: Where do we stand? In IOP Conference Series: Earth and Environmental Science; IOP Publishing: Bristol, UK, 2020; Volume 410. [CrossRef]

50. Cascone, S. Green roof design: State of the art on technology and materials. Sustainability 2019, 11, 3020. [CrossRef]

51. Ottelé, M.; Perini, K.; Fraaij, A.L.A.; Haas, E.M.; Raiteri, R. Comparative life cycle analysis for green façades and living wall systems. Energy Build. 2011, 43, 3419-3429. [CrossRef]

52. Pérez-Urrestarazu, L.; Egea, G.; Franco-Salas, A.; Fernández-Cañero, R. Irrigation systems evaluation for living walls. J. Irrig. Drain. Eng. 2014, 140, 04013024. [CrossRef]

53. Chen, Q.; Li, B.; Liu, X. An experimental evaluation of the living wall system in hot and humid climate. Energy Build. 2013, 61, 298-307. [CrossRef]

54. Widiastuti, R.; Zaini, J.; Caesarendra, W. Field measurement on the model of green facade systems and its effect to building indoor thermal comfort. Meas. J. Int. Meas. Confed. 2020, 166, 108212. [CrossRef]

55. Davtalab, R.; Salamat, A.; Oji, R. Water harvesting from fog and air humidity in the warm and coastal regions in the south of iran. Irrig. Drain. 2013, 62, 281-288. [CrossRef] 
56. Sabino, A. Fog collection in the natural park of Serra Malagueta. An alternative source of water for the communities. In Proceedings of the 4th International Conference on Fog, Fog Collection and Dew, La Serena, Chile, 22-27 July 2007; pp. 425-428.

57. Cereceda, P.; Larrain, H.; Osses, P.; Farías, M.; Egaña, I. The spatial and temporal variability of fog and its relation to fog oases in the Atacama Desert, Chile. Atmos. Res. 2008, 87, 312-323. [CrossRef]

58. Estrela, M.J.; Valiente, J.A.; Corell, D.; Millán, M.M. Fog collection in the western Mediterranean basin (Valencia region, Spain). Atmos. Res. 2008, 87, 324-337. [CrossRef]

59. Harb, O.M.; Salem, M.S.; Abd EL-Hay, G.H.; Makled, K.M. Fog water harvesting providing stability for small Bedwe communities lives in North cost of Egypt. Ann. Agric. Sci. 2016, 61, 105-110. [CrossRef]

60. Lekouch, I.; Lekouch, K.; Muselli, M.; Mongruel, A.; Kabbachi, B.; Beysens, D. Rooftop dew, fog and rain collection in southwest Morocco and predictive dew modeling using neural networks. J. Hydrol. 2012, 60-72. [CrossRef]

61. Dodson, L.L.; Bargach, J. Harvesting Fresh Water from Fog in Rural Morocco: Research and Impact Dar Si Hmad's Fogwater Project in Aït Baamrane. Procedia Eng. 2015, 107, 186-193. [CrossRef]

62. Park, K.C.; Chhatre, S.S.; Srinivasan, S.; Cohen, R.E.; McKinley, G.H. Optimal design of permeable fiber network structures for fog harvesting. Langmuir 2013, 29, 13269-13277. [CrossRef]

63. Almasian, A.; Chizari Fard, G.; Mirjalili, M.; Parvinzadeh Gashti, M. Fluorinated-PAN nanofibers: Preparation, optimization, characterization and fog harvesting property. J. Ind. Eng. Chem. 2018, 62, 146-155. [CrossRef]

64. Zhou, H.; Jing, X.; Guo, Z. Excellent fog droplets collector via an extremely stable hybrid hydrophobic-hydrophilic surface and Janus copper foam integrative system with hierarchical micro/nanostructures. J. Colloid Interface Sci. 2020, 561, 730-740. [CrossRef]

65. Ghosh, R.; Ray, T.K.; Ganguly, R. Cooling tower fog harvesting in power plants-A pilot study. Energy 2015, 89, 1018-1028. [CrossRef]

66. Ghosh, R.; Sahu, R.P.; Ganguly, R.; Zhitomirsky, I.; Puri, I.K. Photocatalytic activity of electrophoretically deposited $\mathrm{TiO} 2$ and $\mathrm{ZnO}$ nanoparticles on fog harvesting meshes. Ceram. Int. 2020, 46, 3777-3785. [CrossRef]

67. Bagheri, F. Performance investigation of atmospheric water harvesting systems. Water Resour. Ind. 2018, 20, 23-28. [CrossRef]

68. Klemm, O.; Schemenauer, R.S.; Lummerich, A.; Cereceda, P.; Marzol, V.; Corell, D.; Van Heerden, J.; Reinhard, D.; Gherezghiher, T.; Olivier, J.; et al. Fog as a fresh-water resource: Overview and perspectives. Ambio 2012, 41, 221-234. [CrossRef]

69. Schemenauer, R.S.; Cereceda, P. A Proposed Standard Fog Collector for Use in High-Elevation Regions. J. Appl. Meteorol. 1994. [CrossRef]

70. Seo, D.; Lee, J.; Lee, C.; Nam, Y. The effects of surface wettability on the fog and dew moisture harvesting performance on tubular surfaces. Sci. Rep. 2016, 6, 24276. [CrossRef]

71. Regalado, C.M.; Ritter, A. On the estimation of potential fog water collection from meteorological variables. Agric. For. Meteorol. 2019. [CrossRef]

72. Rajaram, M.; Heng, X.; Oza, M.; Luo, C. Enhancement of fog-collection efficiency of a Raschel mesh using surface coatings and local geometric changes. Colloids Surf. A Physicochem. Eng. Asp. 2016, 508, 218-229. [CrossRef]

73. Pirouz, B.; Arcuri, N.; Pirouz, B.; Palermo, S.A.; Turco, M.; Maiolo, M. Development of an assessment method for evaluation of sustainable factories. Sustainability 2020, 12, 1841. [CrossRef]

74. Pirouz, B.; Arcuri, N.; Maiolo, M.; Talarico, V.C.; Piro, P. A new multi-objective dynamic model to close the gaps in sustainable development of industrial sector. In Proceedings of the IOP Conference Series: Earth and Environmental Science, Sustainability in the Built Environment for Climate Change Mitigation: SBE19, Thessaloniki, Greece, 23-25 October 2019; Volume 410. [CrossRef]

75. de Dios Rivera, J.; Lopez-Garcia, D. Mechanical characteristics of Raschel mesh and their application to the design of large fog collectors. Atmos. Res. 2015, 151, 250-258. [CrossRef]

76. de Dios Rivera, J. Aerodynamic collection efficiency of fog water collectors. Atmos. Res. 2011, 102, 335-342. [CrossRef]

77. Calderón, M.; Cereceda, P.; Larrain, H.; Osses, P.; Pérez, L.; Ibáñez, M. Alto Patache fog oasis in the Atacama Desert: Geographical basis for a sustainable development program. In Proceedings of the 5th International Conference on Fog, Fog Collection and Dew, Münster, Germany, 25-30 July 2010. 
78. Larrain, H.; Velásquez, F.; Cereceda, P.; Espejo, R.; Pinto, R.; Osses, P.; Schemenauer, R.S. Fog measurements at the site "Falda Verde" north of Chañaral compared with other fog stations of Chile. Atmos. Res. 2002, 64, 273-284. [CrossRef]

79. Tony New Tojquia Project Completed. 2020. Available online: http:/www.fogquest.org/latest-news/ (accessed on 25 September 2020).

80. Schemenauer, R.S.; Osses, P.; Leibbrand, M. Fog Collection Evaluation and Operational Projects in the Hajja Governorate, Yemen. In Proceedings of the Third International Conference on Fog, Fog Collection and Dew, Cape Town, South Africa, 11-15 October 2004.

81. Khaledi, C.K.A. Projection of harvestable water from air humidity using artificial neural network (Case study: Chabahar port). Ital. J. Agrometeorol. 2019, 1, 3-11. [CrossRef]

82. FogQuest: Sustainable Water Solutions. Available online: http://www.fogquest.org/ (accessed on 28 September 2020).

83. Fessehaye, M.; Abdul-Wahab, S.A.; Savage, M.J.; Kohler, T.; Gherezghiher, T.; Hurni, H. Fog-water collection for community use. Renew. Sustain. Energy Rev. 2014, 29, 52-62. [CrossRef]

84. Olivier, J.; De Rautenbach, C.J. The implementation of fog water collection systems in South Africa. Atmos. Res. 2002, 64, 227-238. [CrossRef]

85. Holmes, R.; de Dios Rivera, J.; de la Jara, E. Large fog collectors: New strategies for collection efficiency and structural response to wind pressure. Atmos. Res. 2015, 151, 236-249. [CrossRef]

86. LeBoeuf, R.; de la Jara, E. Quantitative goals for large-scale fog collection projects as a sustainable freshwater resource in northern Chile. Water Int. 2014, 39, 431-450. [CrossRef]

87. Qadir, M.; Jiménez, G.C.; Farnum, R.L.; Dodson, L.L.; Smakhtin, V. Fog water collection: Challenges beyond technology. Water 2018, 10, 372. [CrossRef]

88. Sobczyk, M.; Mrowiec, M. Retention capacity of extensive green roofs. J. Water Land Dev. 2016, 30, $113-117$. [CrossRef]

89. Buccola, N.; Spolek, G. A pilot-scale evaluation of greenroof runoff retention, detention, and quality. Water Air Soil Pollut. 2011, 216, 83-92. [CrossRef]

90. Stovin, V.; Vesuviano, G.; Kasmin, H. The hydrological performance of a green roof test bed under UK climatic conditions. J. Hydrol. 2012, 414, 148-161. [CrossRef]

91. Bevilacqua, P.; Mazzeo, D.; Arcuri, N. Thermal inertia assessment of an experimental extensive green roof in summer conditions. Build. Environ. 2018, 131, 264-276. [CrossRef]

92. MacIvor, J.S.; Margolis, L.; Perotto, M.; Drake, J.A.P. Air temperature cooling by extensive green roofs in Toronto Canada. Ecol. Eng. 2016, 95, 36-42. [CrossRef]

93. Coma, J.; Pérez, G.; Solé, C.; Castell, A.; Cabeza, L.F. Thermal assessment of extensive green roofs as passive tool for energy savings in buildings. Renew. Energy 2016, 85, 1106-1115. [CrossRef]

94. Santamouris, M. Cooling the cities-A review of reflective and green roof mitigation technologies to fight heat island and improve comfort in urban environments. Sol. Energy 2014, 103, 682-703. [CrossRef]

95. Arabi, R.; Shahidan, M.; Kamal, M.S.; Jaafar, M.; Rakhshandehroo, M. Mitigating Urban Heat Island Through Green Roofs. Curr. World Environ. 2015, 10, 918-927. [CrossRef]

96. Razzaghmanesh, M.; Beecham, S.; Salemi, T. The role of green roofs in mitigating Urban Heat Island effects in the metropolitan area of Adelaide, South Australia. Urban For. Urban Green. 2016, 15, 89-102. [CrossRef]

97. Susca, T.; Gaffin, S.R.; Dell'Osso, G.R. Positive effects of vegetation: Urban heat island and green roofs. Environ. Pollut. 2011, 159, 2119-2126. [CrossRef]

98. Fassman-beck, E.; Simcock, R. Hydrology and Water Quality of Living Roofs in Auckland. In Proceedings of the 8th International NOVATECH Conference: Planning and Technologies for Sustainable Urban Water Management, Lyon, France, 23-27 June 2013; pp. 1-10.

99. Liu, Y.; Cibin, R.; Bralts, V.F.; Chaubey, I.; Bowling, L.C.; Engel, B.A. Optimal selection and placement of BMPs and LID practices with a rainfall-runoff model. Environ. Model. Softw. 2016, 80, 281-296. [CrossRef]

100. Yang, H.S.; Kang, J.; Choi, M.S. Acoustic effects of green roof systems on a low-profiled structure at street level. Build. Environ. 2012, 50, 44-55. [CrossRef]

101. Veisten, K.; Smyrnova, Y.; Klæboe, R.; Hornikx, M.; Mosslemi, M.; Kang, J. Valuation of green walls and green roofs as soundscape measures: Including monetised amenity values together with noise-attenuation values in a cost-benefit analysis of a green wall affecting courtyards. Int. J. Environ. Res. Public Health 2012, 9, 3770-3788. [CrossRef] 
102. Van Renterghem, T.; Botteldooren, D. Reducing the acoustical façade load from road traffic with green roofs. Build. Environ. 2009, 44, 1081-1087. [CrossRef]

103. Benvenuti, S. Wildflower green roofs for urban landscaping, ecological sustainability and biodiversity. Landsc. Urban Plan. 2014, 124, 151-161. [CrossRef]

104. Mayrand, F.; Clergeau, P. Green roofs and greenwalls for biodiversity conservation: A contribution to urban connectivity? Sustainability 2018, 10, 985. [CrossRef]

105. Hui, S.C.M.; Chan, M.K.L. Biodiversity assessment of green roofs for green building design. In Proceedings of the Joint Symposium 2011 on Integrated Building Design in the New Era of Sustainability, Hong Kong, China, 22 November 2011.

106. Ichihara, K.; Cohen, J.P. New York City property values: What is the impact of green roofs on rental pricing? Lett. Spat. Resour. Sci. 2011, 4, 21-30. [CrossRef]

107. Farid, F.H.M.; Ahmad, S.S.; Raub, A.B.A.; Shaari, M.F. Green "Breathing Facades" for Occupants' Improved Quality of Life. Procedia Soc. Behav. Sci. 2016, 234, 173-184. [CrossRef]

108. Tsantopoulos, G.; Varras, G.; Chiotelli, E.; Fotia, K.; Batou, M. Public perceptions and attitudes toward green infrastructure on buildings: The case of the metropolitan area of Athens, Greece. Urban For. Urban Green. 2018, 34, 181-195. [CrossRef]

Publisher's Note: MDPI stays neutral with regard to jurisdictional claims in published maps and institutional affiliations.

(C) 2020 by the authors. Licensee MDPI, Basel, Switzerland. This article is an open access article distributed under the terms and conditions of the Creative Commons Attribution (CC BY) license (http://creativecommons.org/licenses/by/4.0/). 